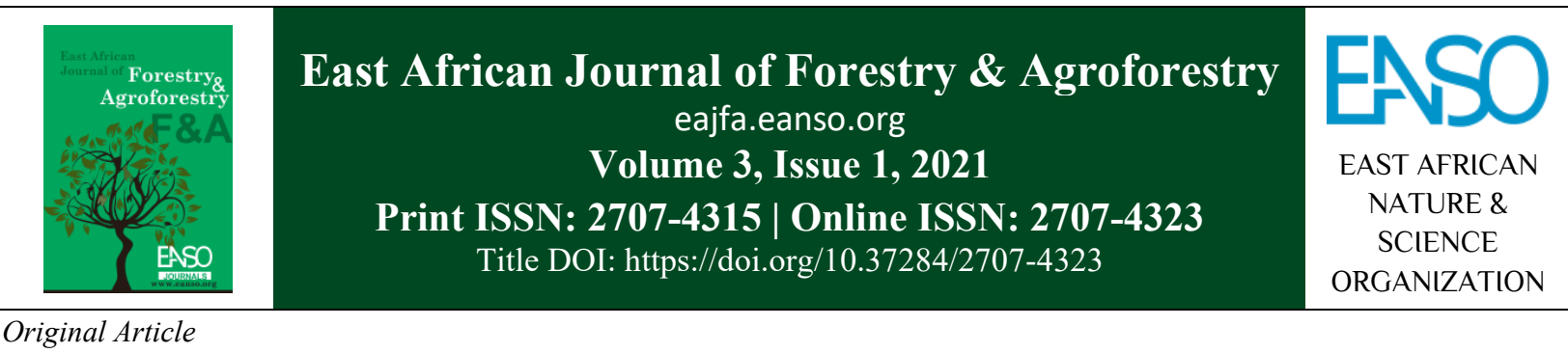

\title{
Variability of Seed Germination and Seedling Growth Potential of Ricinodendron heudelotii (Euphorbiaceae) at Fine Scale in Southern of Benin
}

Yves Yatindo Boko-Haya ${ }^{1}$, Prof. Christine A. I. N. Ouinsavi ${ }^{1}$, Dr. Eben-Ezer B. K. Ewédjè ${ }^{2}$, Yanick Y. Akin ${ }^{1}$, Thérence Zinkpe ${ }^{3}$ \& Prof. Clément Agbangla ${ }^{4}$

${ }^{1}$ Laboratory of Forest Studies and Research, Faculty of Agronomy, University of Parakou, BP 123 Parakou/ Benin.

${ }^{2}$ Laboratoire de Biologie, Ecologie végétale appliquée et de génétique forestière, Faculté des Sciences et Techniques de DassaZoumè, Université Nationale des Sciences, Technologies, Ingénierie et Mathématiques, Abomey, Benin.

${ }^{3}$ Laboratoire de Biomathématiques et d'Estimations Forestières, Faculté des Sciences Agronomiques, Université d'AbomeyCalavi, 04 BP 1525, Cotonou Bénin.

${ }^{4}$ Molecular Genetics and Genome Analysis Laboratory, Faculty of Science and Technology, University of Abomey-Calavi, 01BP 526, Cotonou, Benin.

* ORCID: https://orcid.org/0000-0002-9726-1818; Author for Correspondence email: tadagbemetin@gmail.com.

Article DOI: https://doi.org/10.37284/eajfa.3.1.270

Article history: ABSTRACT

06 February 2021

Keywords:

Seed Quality,

Seed Source,

Dormancy Lifting,

Reforestation,

Ricinodendron heudelotii (Baill.),

Benin.
Ricinodendron heudelotii (Euphorbiaceae) is an oilseed plant with high socioeconomic value. Unfortunately, the seed's tegumentary dormancy causes low germination and severely limits its large-scale spread. Germination and juvenile growth of eleven provenances from Benin and Central African Republics were tested under four different pre-treatments (control, lime scarification, soaking in water for seven days and scarification followed by soaking in water for three days) in order to provide information for use in the reforestation and improvement of $R$. heudelotii. In a Fischer block with three replicates of ten seeds, the daily and final germination (nine months) was recorded and the cumulative germination rate, average germination time and survival rate were calculated. In addition, total height, diameters at the collar and above the cotyledons, internode length, total number of leaves and seedling internodes were measured quarterly. Germination and growth of juveniles were significantly different between provenances and pre-treatments. The highest germination rate (\%) in short duration (d) was recorded with seeds both scarified and soaked for three days in water from Akouho $(20 \%, 42.08 \mathrm{~d})$, CRAPP (36.67\%, 18.82 d), Agrimey (33.33\%, 18.30 d), Ilikimou (26.67\%, $19.94 \mathrm{~d})$ and Woroko $(26.67 \%, 19.25 \mathrm{~d})$ and then lime scarified seeds from Massi (80\%, 14.46 d), Itchede (80\%, 21.29 d) and Lobaye $(60 \%, 19.11 \mathrm{~d})$. Seedlings from seeds that were scarified and soaked for three days in water 
showed optimal growth for all traits; Lobaye and CRAPP provenances showed the best height growth $(33.22 \pm 1.45$ and $31.96 \pm 1.15 \mathrm{~cm})$ while Massi and Illikimou provenances showed the best growth in collar diameter $(1.08 \pm 0.06$ and $1.11 \pm 0.09 \mathrm{~cm})$. Provenances and pre-treatments revealed a discrete variation in germination and growth of $R$. heudelotii. Scarification on the one hand and scarification coupled with soaking into the water for three days on the other hand, are the best pre-treatments to increase seedling production while the best provenances are Lobaye, Massi and Itchede. These provenances are potential seed sources for Forestation Program in Benin.

\section{APA CITATION}

Boko-Haya, Y. Y., Ouinsavi, C. A. I. N., Ewédjè, E. B. K., Akin, Y. Y., Zinkpe, T., \& Agbangla, C. (2021). Variability of Seed Germination and Seedling Growth Potential of Ricinodendron heudelotii (Euphorbiaceae) at Fine Scale in Southern of Benin. East African Journal of Forestry and Agroforestry, 3(1), 1-17. https://doi.org/10.37284/eajfa.3.1.270

\section{CHICAGO CITATION}

Boko-Haya, Yves Yatindo, Christine A. I. N. Ouinsavi, Eben-Ezer B. K. Ewédjè, Yanick Y. Akin, Thérence Zinkpe, and Clément Agbangla. 2021. "Variability of Seed Germination and Seedling Growth Potential of Ricinodendron heudelotii (Euphorbiaceae) at Fine Scale in Southern of Benin". East African Journal of Forestry and Agroforestry 3 (1), 1-17. https://doi.org/10.37284/eajfa.3.1.270.

\section{HARVARD CITATION}

Boko-Haya, Y. Y., Ouinsavi, C. A. I. N., Ewédjè, E. B. K., Akin, Y. Y., Zinkpe, T., and Agbangla, C. (2021) "Variability of Seed Germination and Seedling Growth Potential of Ricinodendron heudelotii (Euphorbiaceae) at Fine Scale in Southern of Benin”, East African Journal of Forestry and Agroforestry, 3(1), pp. 1-17. doi: 10.37284/eajfa.3.1.270.

\section{IEEE CITATION}

Y. Y. Boko-Haya, C. A. I. N. Ouinsavi, E. B. K. Ewédjè, Y. Y. Akin, T., Zinkpe, and C. Agbangla, "Variability of Seed Germination and Seedling Growth Potential of Ricinodendron heudelotii (Euphorbiaceae) at Fine Scale in Southern of Benin", EAJFA, vol. 3, no. 1, pp. 1-17, Feb. 2021.

\section{MLA CITATION}

Boko-Haya, Yves Yatindo, Christine A. I. N. Ouinsavi, Eben-Ezer B. K. Ewédjè, Yanick Y. Akin, Thérence Zinkpe, and Clément Agbangla. "Variability of Seed Germination and Seedling Growth Potential of Ricinodendron heudelotii (Euphorbiaceae) at Fine Scale in Southern of Benin". East African Journal of Forestry and Agroforestry, Vol. 3, no. 1, Feb. 2021, pp. 1-17, doi:10.37284/eajfa.3.1.270.

\section{INTRODUCTION}

Seed germination is a priority in programs for the restoration, conservation and sustainability of forest reserves. Efficient germination, rapid growth and seedling survival are priority characteristics sought in forest restoration (Campos Filho and Sartorelli, 2015). Some seeds have an integumentary dormancy that inhibits germination under normal conditions (Imchen et al., 2015). Therefore, pretreatments are applied to suppress dormancy and increase the germination rate of these seeds (Debroux et al., 1998). Several authors have shown that mechanical scarification (Ye et al., 2019; AlFredan and Ali, 2008), water immersion (Hossain et al., 2018; Marie-Thérèse et al., 2012; Kumar et al.,
2007) are pre-treatments that contribute to increasing the germination rate and juvenile growth of seedlings of several useful plant species.

Ricinodendron heudelotii (Baill.), commonly called African wood oil nut tree belongs to the family Euphorbiaceae and is localised from Guinea to Angola (Vivien and Faure, 1985) and Madagascar (Heim et al., 1919). It is a polyvalent species, whose seeds are oleaginous and proteinous (Busson, 1965; Kapseu and Tchiegang, 1995; Tchiegang et al., 2003; Kouame et al., 2015), rich in nutrients and minerals and regularly consumed by local populations (Saki et al., 2005). Leaves and bark have medicinal functions against ovarian cysts (Ngene et al., 2015); obstetric fistulas (Lagou et al., 2016); haemorrhoids (Dibong et al., 2015); kidney 
problems, injuries and muscle pain (Nole et al., 2016). The leaves also have a purgative effect (N'guessan et al., 2009) and facilitate childbirth in association with Ehretia cymosa (N'guessan et al., 2011). The trade of seeds on the European market significantly increases the economy and survival of farmers (Cosyns et al., 2011; Tabuna, 1999) and women (Ayuk et al., 1999). The almond is a potential raw material for agro-food industries (Tchiegang et al., 1997) and makes the species to be the 3rd priority one in West Africa (Leakey and Tomich, 1999), and that should be introduced in agroforestry to meet an ever-increasing demand (FAO, 2016).

In Benin, once considered the most abundant species $(77.6 \%)$ in the tree stratum of the semideciduous Pobè forest (Sokpon, 1995), it is currently rare in open areas. Therefore, the exploitation of $R$. heudelotii has already reached protected areas at the request of the Royal Authority (A. Badou, personal communication, September 2018). Indeed, Guèlèdè masks, mainly made from the wood of $R$. heudelotii (Boko-haya et al., 2017) have now acquired a high market value due to the tourism associated with them since the recognition of Guèlèdè as intangible heritage by UNESCO in 2010.

However, seeds of this species do not germinate without prior treatment (Mapongmetsem et al., 1999) due to their tegumentary dormancy (Djeugap et al., 2014). In view of its multiple uses, the lifting of seed inhibition in the germination process has been discussed by several authors. The suppression of seed coat dormancy was tested by soaking seeds in water (Katende et al., 1995), by lime scarification (Vivien and Faure, 1996) with a germination rate of $40 \%$, or by hammer scarification with a germination rate of $88 \%$ (Djeugap et al., 2014). It has been reported that the seed source is also a key factor influencing germination rate and seedling growth (Akaffou et al., 2019; Bischoff et al., 2010; Fredrick et al., 2017; Kheloufi and Mansouri, 2017; Fredrick et al., 2015).
Due to the ongoing anthropic pressure in Benin and especially its sharply increasing demand, there is an urgent need to seek sources of seeds with better germination performance. With the aim of valorising this species in Benin in order to exploit its oleaginous potential within the framework of research on species with strong biofuel properties, the present study was conducted. The study aimed at testing the provenances (Benin ones and Central African's) and the different pre-treatments on seed germination rate in order to identify the best ones for germplasm collection for large-scale production. The fundamental question of the study was which pre-treatments and seed provenances offer the best germination rate and juvenile growth of $R$. heudelotii? The objective of this study is to test the influence of various pre-treatments and seed sources on germination and juvenile growth of $R$. heudelotii. This study will provide an information base for the choice of early selection criteria to be taken into account in future $R$. heudelotii seedling production and selection programs.

\section{MATERIAL AND METHODS}

\section{Study Environment}

The germination test was carried out in the Akassato district (6³0'25.207 “N, 2²0'58.382 “E, $39.01767 \mathrm{~m}$ ) characterised by a sub-equatorial climate with two dry seasons and two rainy seasons. The long rainy season extends from mid-March to mid-July and the short one from mid-September to mid-November, with an average annual rainfall of $1500 \mathrm{~mm}$ and an average temperature of $27^{\circ} \mathrm{C}$. The $R$. heudelotii seeds used to come from two southern Phyto districts (Pobè and Plateau) located in the Guinean climatic zone where the average annual rainfall is $1200 \mathrm{~mm}$ and the average temperature is between $25^{\circ} \mathrm{C}$ and $29^{\circ} \mathrm{C}$ (Figure 1). The soils are deep ferritic with low fertility. In addition, exotic seeds from the Central African Republic were collected in the semi-deciduous dense forest of the Lobaye under a Guinean forest-type climate (Aubréville, 1984) with ferritic soils of relatively low fertility (Boulvert, 1996). 
East African Journal of Forestry and Agroforestry, Volume 3, Issue 1, 2021

Article DOI: https://doi.org/10.37284/eajfa.3.1.270

Figure 1: Areas of the study in the Benin Republic

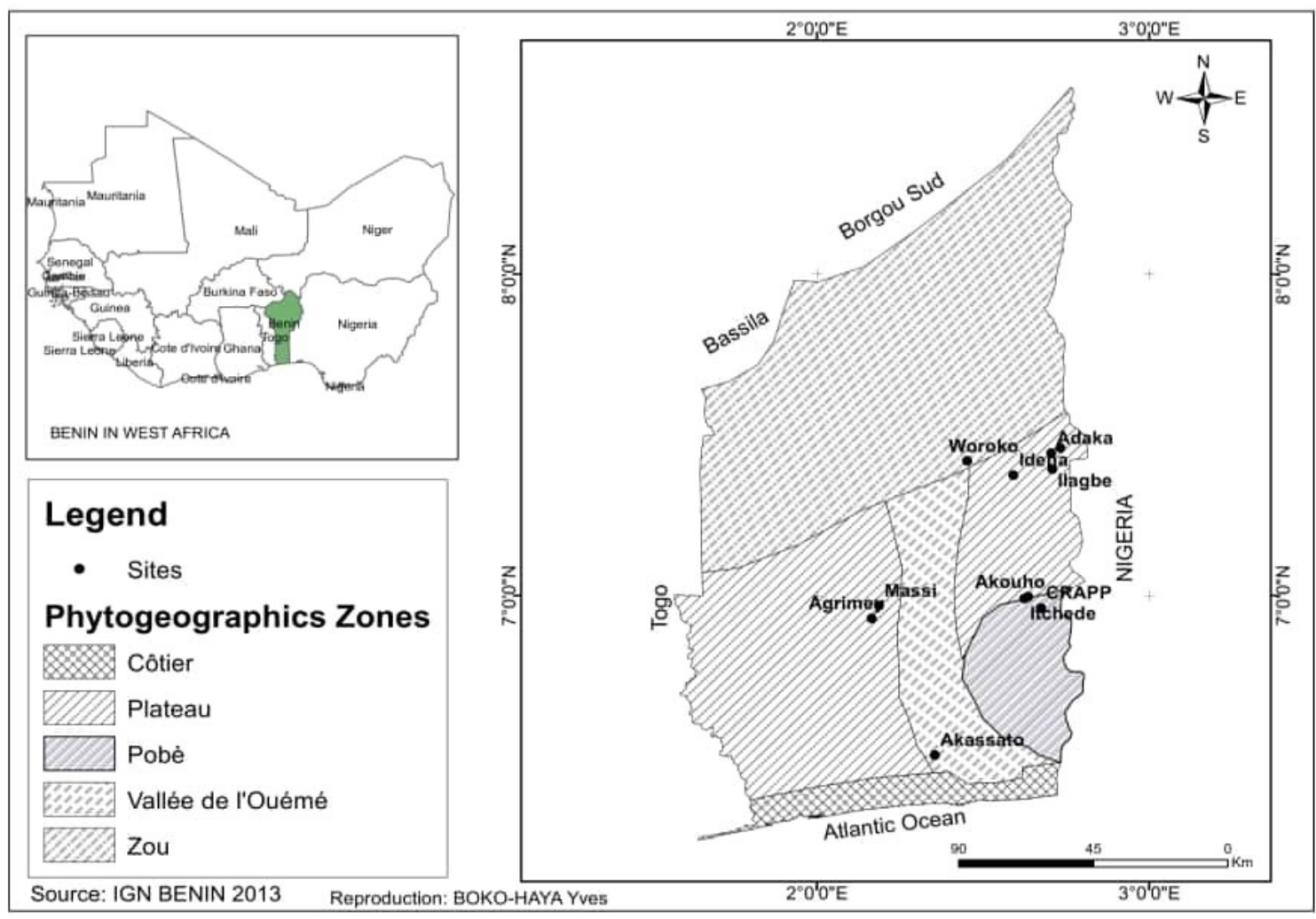

Figure 2: Areas of the study in the Central African Republic

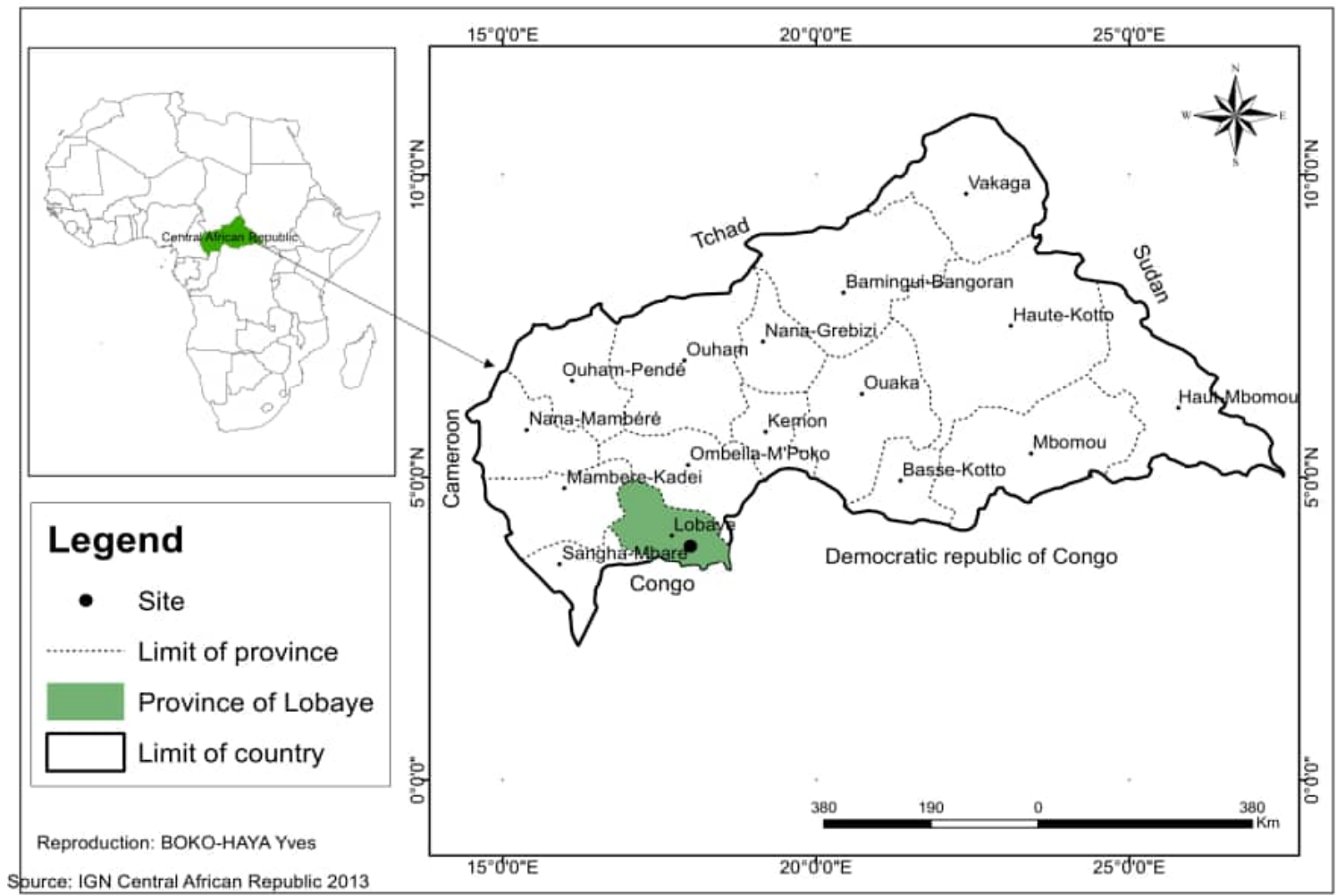




\section{Plant Material and Sampling}

The sites sampled were the Akouho and CRAPP (Agricultural Research Centre for Perennial Plants) forests in the commune of Pobè; the Agrimey and Massi sectors of the Lama forest in the commune of Zogbodomey; Adaka, Ilikimou and Woroko sites in the commune of Kétou and the Itchede forest in the commune of Adja-Ouèrè. All these sites are located in the Plateau Phyto district except the CRAPP site located in the Pobè Phyto district (Figure $1 \& 2$ ). The choice of site was related to habitat and the presence of productive mother trees. Each mother tree provided 200 healthy seeds manually extracted from fruits harvested. In addition, the sample contains a batch of exotic seeds harvested from the Central African Republic in the semi-deciduous dense forest of the Lobaye. All seeds were stored at room temperature in accordance with the seed drying standards set by the International Rules for Seed Testing (ISTA, 2005). Seeds were sorted by removing those with physical cracks or microbial attack.

\section{Experimental Design and Data Collected}

Fisher's blocks were used to set up treatments. Two factors were considered: seed pre-treatment and seed provenances. As far as seed pre-treatment is concerned, four levels were considered: T0 (control), T1 (seeds mechanically scarified without damaging the embryo), T2 (seeds soaked into water for 7 days) and T3 (seeds scarified then soaked into water for 3 days). Regarding seed provenances, nine (9) modalities were considered which are: Akouho, CRAPP, Itchede, Woroko, Illikimou, Adaka, Agrimey and Massi in Benin and Lobaye in the Central African Republic. A total of 4 x 9 (36) treatments randomly distributed into 3 blocks were established. Each treatment was repeated three (03) times. Each seed was sown in a polyethene bag $(\mathrm{H}$ $=20 \mathrm{~cm}, \mathrm{D}=12 \mathrm{~cm}$ ). The pots were watered every three days, in the morning and evening. No fertilisers or plant protection products were used in order to respect the germination conditions in the natural environment of the seeds. The pots were sheltered using palm tree leaves resting on vertical stakes of two (2) meters high.

As far as data collection is concerned, seed germination was recorded as soon as an opening appeared on the soil surface, revealing the cotyledon or stem. Thus, the number of germinated seeds was counted daily for the duration of the trial (273 days). Growth parameters (collar diameter, total height, number of leaves, length of internodes, number of internodes, diameter above the cotyledon) were measured quarterly on each plant up to 9 months age, using a calliper and a graduated ruler.

\section{Data Analysis}

Average germination time (Bewley \& Black, 1994) and germination rate (Côme D., 1968; Événari M., 1957) were calculated as well as changes in survival rate. Data related to seed germination were submitted to a generalised linear mixed model (binary family) on glmmTMB package (Brooks et al., 2017) to assess the effects of pre-treatments and provenance on the ability of the seed to emerge. Effects of provenance and pre-treatments on growth parameters of $R$. heudelotii were tested using linear mixed models effects on longitudinal data in the nlme package (Pinheiro et al., 2017) excepted the number of internodes and the total number of leaves for which generalised linear mixed model effects were used on the package glmmTMB (Brooks et al., 2017). The modelling process consisted of testing the effects of random factor (block) and duration, using unconditional mean and unconditional growth models, respectively. The effect related to each model was obtained through the inter-class correlation coefficient (ICC). The test structures of the variance-covariance matrix for the residuals of the established models were chosen using the likelihood ratio test (LRT). The best model was selected and allowed to assess the effects of the main factors (models with interaction). Finally, trend curves were constructed for illustration and description purposes.

As far as survival rate and germination time are concerned, binary logistic regression and generalised linear model of Poisson family (negative binomial error) were used to assess the effects of treatments. All statistical analyses were performed using R 3.6.1 (R Core Team, 2019) and $p<0.05$ was used as a rejection criterion for the null hypothesis. 


\section{RESULTS}

\section{Effect of Seed Provenances and Pre-treatment on Germination Parameters}

The results of the binary model showed that the germination rate was significantly affected by the provenance of the seed $(p<0.05)$, the pre-treatment $(p<0.05)$ and the interaction of both of them $(p<$ $0.05)$, suggesting that the dynamics of the seeds were to be germinated according to the pretreatments differ from one provenance to another.

For all provenances, the germination rate increased to a maximum value with treatments $\mathrm{T} 1$ and $\mathrm{T} 3$ and then decreased with treatment T2 (see Figure 3). However, the treatments with the highest germination rates vary from one provenance to another. For example, for seeds harvested at Lobaye, Massi and Itchede, the highest germination rates were recorded with the $\mathrm{T} 1$ treatment (respectively $60 \%, \quad 80.0 \%$ and $80.0 \%$ as germination rate values) (see Figure 3). While for seeds collected from Ilikimou, Woroko Agrimey, CRAPP and Akouho, the highest germination rate was recorded with $\mathrm{T} 3$, the respective values being $26.67 \%, 26.67 \%, 33.33 \%, 36.67 \%$ and $40.0 \%$. The Adaka provenance has the highest germination rate (20\%) for both T1 and T3 treatments. Only Massi has the highest germination rate for all treatments ( $\mathrm{T} 1=80 \%, \mathrm{~T} 2=60 \%$ and $\mathrm{T} 3=66.67 \%)$; Massi is therefore the best seed source. With a germination rate of $66.67 \%$ for control, Massi suggests that $R$. heudelotii seeds do not need pre-treatments to germinate (see Figure 3).

Figure 3: Average germination rate by pre-treatment and seed provenance of $\boldsymbol{R}$. heudelotii

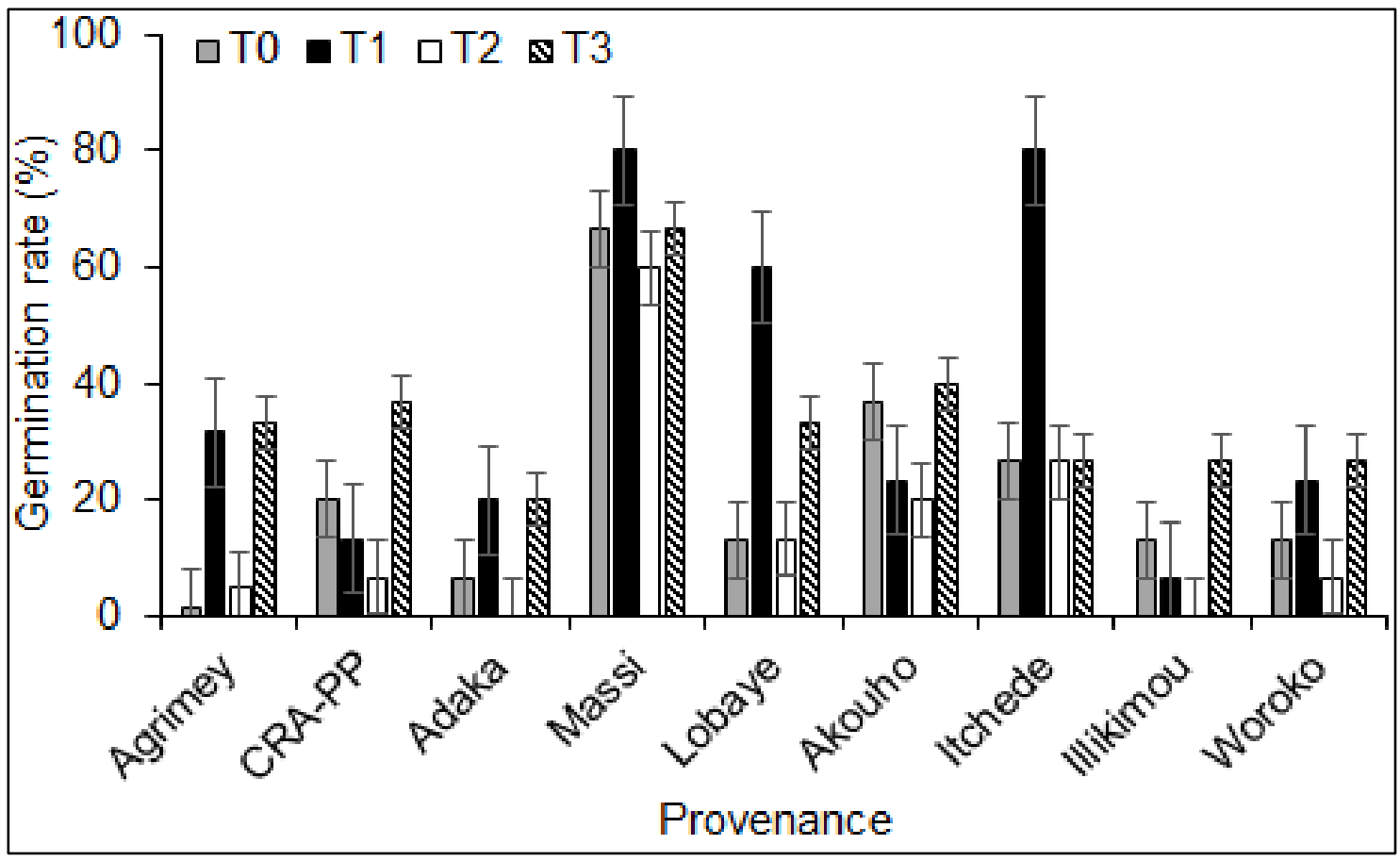

T0: control, T1: mechanically scarified, T2: soak in water for 7 days, T3: Scarify and soak in water for 3 days

In addition, the results of the generalized linear model showed that the mean germination time was significantly affected by provenance $(\mathrm{RD}=479.34$; $p<0.001)$, pre-treatments $(\mathrm{RD}=558.68, p<0.001)$ and their interactions $(\mathrm{RD}=400.22 ; p<0.001)$. Seed source and pre-treatments are, therefore, two main factors whose appropriate choices could contribute to reducing the mean seed germination duration in $R$. heudelotii.

For all provenances, the average germination duration was reduced with all treatments (see 
Figure 4). The shortest mean germination duration was obtained with $\mathrm{T} 3$ for the provenances of Akouho, Lobaye, Massi and Itchede, the respective values being 13.96, 14.4, 15.2 and 16.6 days; i.e., a reduction of one (Itchede, Lobaye), two (Massi) and
3 weeks (Akouho) of the mean germination time compared to the control. Akouho provenance showed a longer average germination duration (44.18 days) compared to the control treatments (see Figure 4).

Figure 4: Mean germination duration according to pre-treatment and seed provenance of $\boldsymbol{R}$. heudelotii

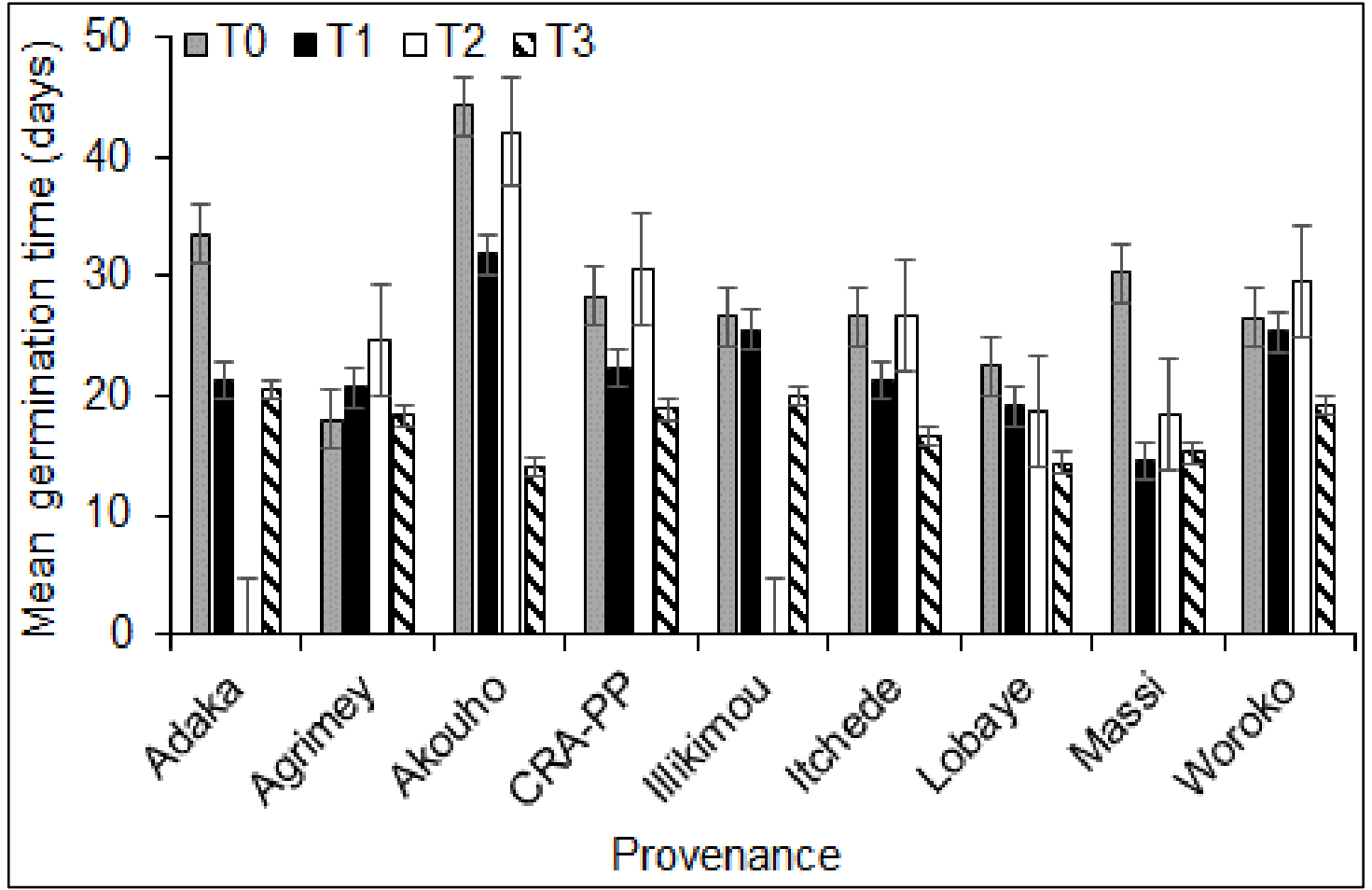

With respect to seedling survival, the results of binary logistic regressions indicated that only seed source made a significant difference $(p=0.002)$. The highest mean survival rate was found in Akouho and Massi, 94\% and 93\% respectively, while the lowest mean survival rate $(69 \%)$ came from Itchede. All provenances had a survival rate above 50\%; this result means that seeds from Benin and the Central African Republic can be used in reforestation programs with a perfect adaptation of Central African seeds to the climatic and soil conditions of South Benin.

\section{Effect of Seed Sources and Seed Retreatments on Seedling Growth}

The result of the linear models (Table 1) showed, over time, a significant difference in seedling growth for all agronomic traits for both pretreatments and provenances. Similarly, timeprovenance interaction also had a significant influence on all agronomic characteristics of seedlings. This means that the growth of seedlings over time varies considerably from one provenance to another. This growth dynamic was maintained for all seedlings throughout the experiment. The interaction between time and pre-treatment was significant only for crown diameter; therefore, growth in diameter thickness on cotyledons differed over time for pre-treatments from one provenance to another. In the absence of germination of Adaka and Ilikimou seeds for T2, the interaction between source and pre-treatment was not evaluated. 
East African Journal of Forestry and Agroforestry, Volume 3, Issue 1, 2021

Article DOI: https://doi.org/10.37284/eajfa.3.1.270

Table 1: Mixed linear and generalised linear model assessing the effect of seed source and pretreatment on $\boldsymbol{R}$. heudelotii plants (effects results)

\begin{tabular}{lllllll}
\hline Source of variation & Lin & Dac & Dc & Tln & Ni & Th \\
\hline Duration & $2962.27 \mathrm{~s}$ & $2431.04 \mathrm{~s}$ & $2622.51 \mathrm{~s}$ & $2192.19 \mathrm{~s}$ & $2361.24 \mathrm{~s}$ & $1472.09 \mathrm{~s}$ \\
Provenances & $33.94 \mathrm{~s}$ & $60.55 \mathrm{~s}$ & $51.29 \mathrm{~s}$ & $275.23 \mathrm{~s}$ & $327.39 \mathrm{~s}$ & $108.88 \mathrm{~s}$ \\
retreatments & $30.36 \mathrm{~s}$ & $07.56 \mathrm{~s}$ & $02.27 \mathrm{~s}$ & $22.59 \mathrm{~s}$ & $21.68 \mathrm{~s}$ & $09.76 \mathrm{~s}$ \\
Duration x Provenances & $07.25 \mathrm{~s}$ & $16.35 \mathrm{~s}$ & $17.20 \mathrm{~s}$ & $44.59 \mathrm{~s}$ & $42.80 \mathrm{~s}$ & $22.52 \mathrm{~s}$ \\
Duration x pre-treatments & $1.43 \mathrm{~ns}$ & $03.03 \mathrm{~s}$ & $2.04 \mathrm{~ns}$ & $03.33 \mathrm{~ns}$ & $06.92 \mathrm{~ns}$ & $01.30 \mathrm{~ns}$ \\
\hline Block CPI (\%) & 0.66 & 0.00 & 0.00 & 0.00 & 0.00 & 0.00 \\
ICC time (\%) & 48.26 & 68.28 & 71.42 & 64.838 & 60.51 & 45.64 \\
\hline ICC time (\%) & 48.26 & 68.28 & 71.42 & 64.838 & 60.51 & 45.64 \\
\hline
\end{tabular}

The F-value (lmme) / deviation (glmme) of the models are presented in the table (s: significant and ns: not significant at 5\%). (Lin: Length of the internode, Dac: Diameter above the cotyledon, Dc: Diameter at the collar, Tln: Total number of leaves, Ni: number of internodes and Th: Total height)

Figure 5 shows the curves describing the evolution of the growth parameters over time. The growth initially dispersed and specific to each provenance tends to become linearised with a rapid increase from the sixth month onwards for all characteristics. The sowings obtained from Itchede and Lobaye seeds (Photo 1) showed the highest values for total height $(33.22 \pm 1.45 \mathrm{~cm}$ and $31.96 \pm 1.15 \mathrm{~cm})$, length of internodes $(7.59 \pm 0.23 \mathrm{~cm}$ and $8.39 \pm 0.34$ $\mathrm{cm})$, number of leaves $(15.83 \pm 0.91$ and $14.22 \pm$ $0.84 \mathrm{~cm})$ and internodes $(13.22 \pm 0.86$ and $11.28 \pm$ $0.79 \mathrm{~cm}$ ); those obtained with Massi seeds showed the highest values for diameter at the collar $(1.08 \pm$ $0.06 \mathrm{~cm})$ and diameter above the cotyledons $(0.81 \pm$ $0.05 \mathrm{~cm}$ ). Adaka seedlings had the lowest values for height $(16.58 \pm 1.06 \mathrm{~cm})$, diameter above the cotyledons $(0.6 \pm 0.05 \mathrm{~cm})$, number of leaves $(10.47$ $\pm 1.06)$ and internodes $(8.06 \pm 1.03)$. 
East African Journal of Forestry and Agroforestry, Volume 3, Issue 1, 2021

Article DOI: https://doi.org/10.37284/eajfa.3.1.270

Figure 5: Trend curve for the variation of growth parameters

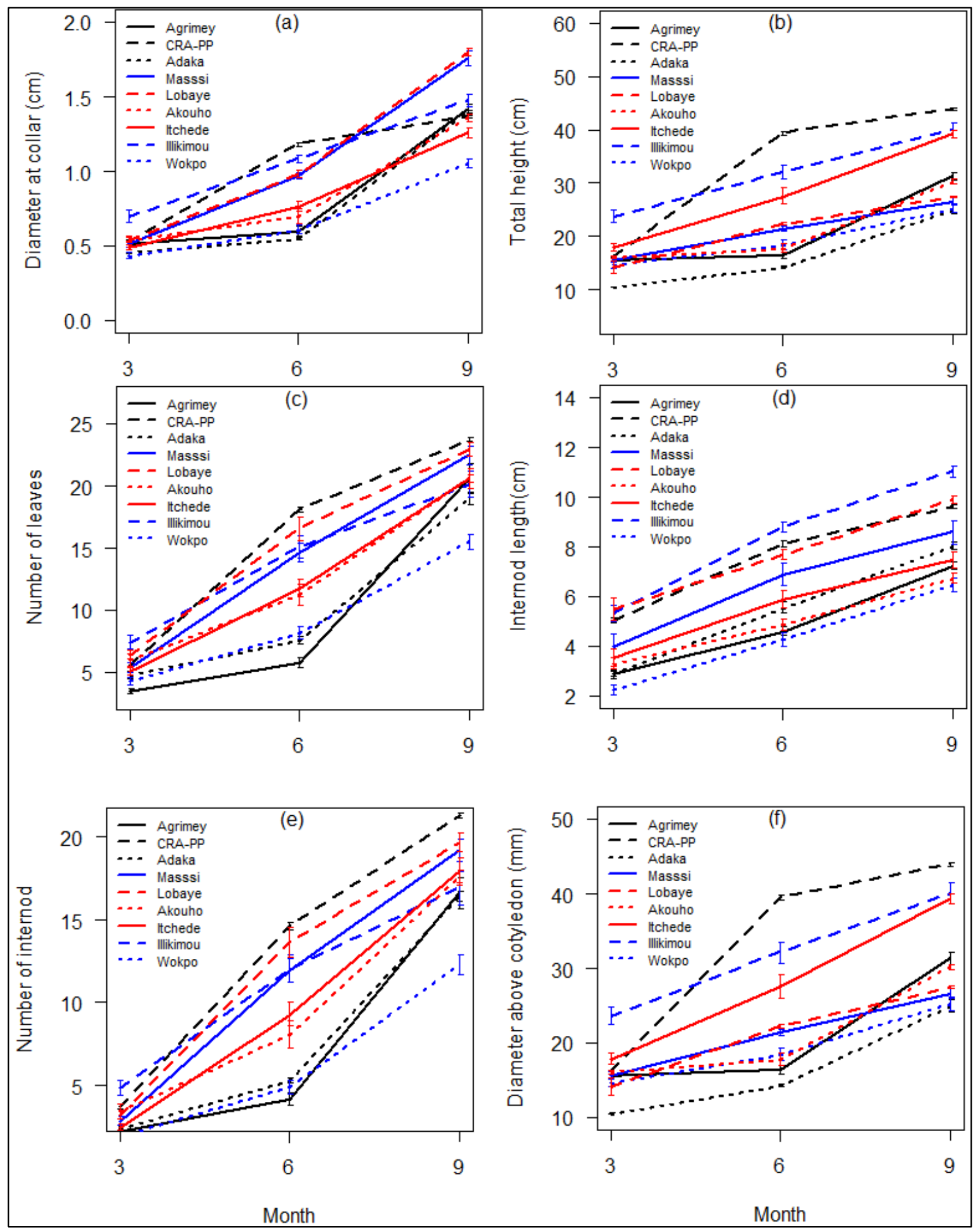

$a$ : Diameter at the collar, $b$ : Total height, $c$ : Number of leaves, $d$ : Length of internode, e: Number of internodes, $f$ : Diameter above the cotyledon) as a function of seed source. 
Photo 1: Growing plants coming from different provenances

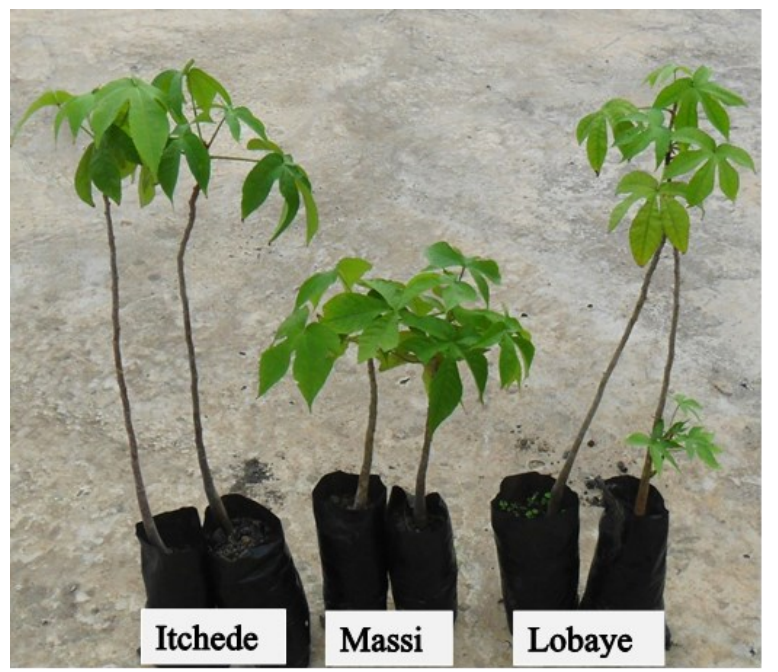

Table 2 shows that pre-treatments made a significant difference in growth parameters. The number of internodes ranged from $9.21 \pm 0.52$ (T1) to $10.92 \pm 0.57(\mathrm{~T} 3)$; the length of internodes ranged from $6.11 \pm 0.26 \mathrm{~cm}(\mathrm{~T} 0)$ to $6.69 \pm 0.19 \mathrm{~cm} \mathrm{(T3);}$ and the total number of leaves ranged from $11.85 \pm$ 0.55 (T1) to $13.73 \pm 0.6$ (T3); the total height ranged from $23.24 \pm 0.91 \mathrm{~cm}$ (T0) to $25.9 \pm 1.2 \mathrm{~cm}$ (T3); the diameter at the collar and above the cotyledon respectively from $0.91 \pm 0.04 \mathrm{~cm}$ (T2) to $0.95 \pm 0.04$ $\mathrm{cm}(\mathrm{T} 3)$ and from $0.64 \pm 0.03(\mathrm{~T} 0, \mathrm{~T} 1)$ to $0.71 \pm$ 0.03 (T3). The T3 treatment showed the maximum values for all agronomic traits except for the total height $(25.9 \pm 1.2 \mathrm{~cm})$ recorded with $\mathrm{T} 2$. On the other hand, the lowest values for the agronomic traits were observed with $\mathrm{T} 0$ with the exception of the collar diameter obtained with $\mathrm{T} 2$.

Table 2: Descriptive statistics (mean \pm standard error) of growth parameters by treatment

\begin{tabular}{lllllll}
\hline & Ni & Lin $(\mathbf{c m})$ & Tln & Dc (cm) & Th (cm) & Dac (cm) \\
\hline T0 & $9.89 \pm 0.63$ & $6.11 \pm 0.26$ & $12.65 \pm 0.67$ & $0.93 \pm 0.04$ & $23.24 \pm 0.91$ & $0.64 \pm 0.03$ \\
T1 & $9.21 \pm 0.52$ & $6.2 \pm 0.2$ & $11.85 \pm 0.55$ & $0.92 \pm 0.03$ & $24.45 \pm 0.78$ & $0.64 \pm 0.02$ \\
T2 & $10.27 \pm 0.81$ & $5.27 \pm 0.31$ & $13.08 \pm 0.85$ & $0.91 \pm 0.04$ & $25.9 \pm 1.2$ & $0.67 \pm 0.03$ \\
T3 & $10.92 \pm 0.57$ & $6.69 \pm 0.19$ & $13.73 \pm 0.6$ & $0.95 \pm 0.04$ & $24.61 \pm 0.77$ & $0.71 \pm 0.03$ \\
\hline
\end{tabular}

(Lin: length of the internode, Dac: Diameter above the cotyledon, Dc: Diameter at the collar, Tln: Total number of leaves, Ni: Number of internodes and Th: total height)

\section{DISCUSSION}

The low germination rate of $R$. heudelotii seeds limits its widespread ability. Applied mechanical scarification (Djeugap et al., 2014; Marie-Thérèse et al., 2012) has increased the germination rate. In the present study, lime scarification, coupled with the soaking of seeds into the water was examined on several geographically distinct provenances to identify the best ones to be used in reforestation and ex-situ introduction programs.

\section{Retreatments and Provenance Revealed a Wide Variation in Germination Parameters}

The germination rate and average germination duration showed a significant variation between provenances and the best pre-treatments were scarified seeds and seeds that were both scarified and soaked into water for three days. This interprovenance variation shows that seeds are heterogeneous between provenances. This heterogeneity would be related to the presence of particular characteristics (Mira et al., 2011; PérezGarcía and González-Benito, 2010) of R. heudelotii seeds from each provenance. This heterogeneity in seed germination is useful for the survival of wild species under unpredictable environmental conditions. Similar results were obtained by Diouf et al. (2015) between provenances of baobabs (Adansonia digitata) with a high variation in seed germination rate, by Moya et al. (2017) with intraand inter-provenance variation in seed germination capacity of Nothofagus glauca and by Mboya et al. (2015) with a significant variation for all germination parameters within provenances in Faidherbia albida. The observed variation in germination, due to the specific characteristics of seeds of each provenance, maybe of physiological, physical and/or genetic origin.

Seed dormancy (Pérez-García et al., 2012) with intraspecific variation such as germination (Baskin and Baskin, 2014; Santo et al., 2015) or inter- 
population variability due to environmental and/or genetic differences (Cruz et al., 2003; Ginwal et al., 2004) are potential factors that may cause variation in seed germination. Thus, the conditions of the mother plants (Baskin and Baskin, 2014; Roach and Wulff, 1987; Bischoff and Müller-Schärer, 2010) affect seed germination characteristics. The genotype and environment of the mother plant have an impact on the degree of primary seed dormancy (Penfield, 2017) and on seed germination (Keller and Kollmann, 1999).

Recently, abscisic acid (ABA) and gibberellic acid (GA) have been identified as the main hormones that antagonistically regulate seed dormancy and germination (Finkelstein et al., 2008; Lee et al., 2015). High ABA and low GA induce deep seed dormancy, while low ABA and high GA induce early germination. The state (dormancy or germination) of a seed is therefore determined by the concentration of the ABA-GA hormone pair. This state is regulated by molecular mechanisms whose expression is linked to a DNA motif (Shu et al., 2016). Thus, differences in the germination behaviour of seeds from different provenances could be explained by a difference in the blocking of the functioning of the molecular regulators responsible for an increase or decrease in the level of the ABA-GA hormone pair. Some molecular regulators, such as the HONSU protein, act as a negative regulator of seed dormancy by simultaneously inhibiting ABA signalling and activation of GA signalling (Kim et al., 2013); for example, the Abscisic Acid Insensitive 4 (ABI4) gene has been identified as a positive regulator of primary seed dormancy that prevents germination (Kong et al., 2015; Shu et al., 2013).

In addition, seed size variation in Carpobrotus edulis (L.) NEBr. (Podda et al., 2018) or seeds in Rubus sp. (Choi et al., 2017) also causes variation in germination within provenances. Aref et al. (2011) added that seed coat hardness in Acacia species is a factor affecting germination. In the present study, the significant difference in germination response between provenances of $R$. heudelotii subjected to different pre-treatments suggests that the seed source is a priority in the choice of the best germplasm. Massi is the best source, paradoxically showing that $R$. heudelotii seeds do not need pretreatment to germinate; which corroborates with the work of Assogbadjo et al. (2011) on baobab. It is, therefore, possible that Massi seeds may have a thin integument that favours easier entry of water to induce rapid germination, as was the case for Dalbergia odorifera seeds (Liu et al., 2017). Under the same climatic gradient and in the same Phyto district, optimal germination was obtained with scarified seeds from Itchede against seeds both scarified and soaked for three days in water from Akouho. This difference could be justified by variations in the soil conditions of the mother trees. Similar results were obtained with Eucalyptus nitens where, the optimal seed germination temperature for Toolangui and MacAlister provenances under the same latitude was significantly different and corresponded to $28{ }^{\circ} \mathrm{C}$ and $18{ }^{\circ} \mathrm{C}$ respectively (Humara et al., 2000), in Eucalyptus ovata, Prosopis alba and Silene dioica (Harrison et al., 2014; Venier et al., 2015).

With regard to seedling survival, a significant difference between provenances was observed, in contrast to pre-treatments. This inter-provenance variation in survival rate would be related to a variation in nutrient reserves in seeds from different provenances (Kitajima and Myers, 2008). For example, sucrose is a major source of energy, used during the early stages of germination in Cicer arietinum (Arunraj et al., 2020); seedlings from seeds with low sucrose levels will not be able to survive. Mortality is low during the establishment phase of seedlings, meaning that most seeds from all sources had a large amount of available nutrients (Harper, 1977). This low mortality suggests that seedlings of Central African provenance in nurseries are likely to adapt well to the climatic conditions in South Benin.

\section{Differences in Growth between Provenances and between Pre-treatments}

This study showed a significant difference in seedling growth for all agronomic traits for both pre-treatments and provenances. Seedling growth was closely related to provenance, which is consistent with seedling growth of Khaya senegalensis (Ky-Dembele et al., 2014); Neolamarckia Cadamba Miq (Sudrajat et al., 2016) and Terminalia ivorensis (Ojo and Ajayi, 2019) where considerable variation was observed within all provenances for all growth traits studied. This 
result contrasts with that of Moya et al. (2017), where the growth of $N$. glauca seedlings was not related to seed provenance. Significant differences in seedling growth and survival rates were dependent on the availability of reserves (carbohydrates, lipids, storage proteins and other mineral nutrients) stored in the seeds until the plants became established (Kitajima and Myers, 2008). Thus, the variation observed between and within provenances may be related to genetic differences between mother plants. Maternal effects highly influence the early seedling stage of a genotype (Roach and Wulff, 1987). In addition, seedling morphology and cotyledon functions have also affected seedling growth rate (Baraloto and Forget, 2007; Kitajima, 1994).

In the current study, germination tests were carried out ex-situ with the same types of substrate and climate; therefore, the significant differences observed in seedling germination and growth parameters could be of genetic origin, i.e., related to a difference in genotype. Baskin and Baskin (2019) stated that the genotype of an individual depends on its parents. For example, the maternal parent has a significant effect on the germination percentage of Betula pendula seeds (Pasonen et al., 2001) while the variation in germination rate of Iris hexagona seeds is partly paternal in origin, i.e., it depends on the pollen donor required for oosphere pollination (Van Zandt and Mopper, 2004). However, these differences may also be related to morphometric variables of seeds or seed coat. The observed intraprovenance variation suggests that restoration programs should take into account the provenances of the seeds (Breed et al., 2013); in other words, each provenance requires specific treatment to achieve the expected performance. Variation in germination and growth characteristics within the population will facilitate the selection of populations and individuals most suitable for mass production.

\section{CONCLUSION}

This study showed that pre-sprouting treatments are an effective means of lifting the dormancy of $R$. heudelotii seeds. Scarification, on the one hand, and scarification combined with a three-day soaking of the seeds in water, on the other hand, proved to be the best pre-treatments. Seeds of Massi germinate more easily and seedlings have the largest collar diameter while Itchede and Lobaye seedlings have the greatest height and internode length. However, it is necessary to test these results obtained by evaluating the morphometric and molecular aspects of the seeds and to extend the study to all other phytogeographical zones of the countries concerned.

\section{ACKNOWLEDGEMENTS}

We sincerely thank Dr Prosper S. Yandia who provided us with the biological material from the Central African Republic; all the agents and forest conservation officers of the CRAPP, Itchede, Lama for their help and accompaniment in the field.

\section{REFERENCES}

Akaffou, S. D., Kouame, A. K., Gore, N. B. B., Abessika, G. Y., Kouassi, H. K., Hamon, P., ... \& Duminil, J. (2019). Effect of the seeds provenance and treatment on the germination rate and plants growth of four forest trees species of Côte d'Ivoire. Journal of Forestry Research, $1-9$.

Al-Fredan, M. A., \& Ali, Y. S. (2008). Seed scarification requirement in doum (Hyphaene thebaica Mart.). Scientific Journal of King Faisal University (Basic and Applied Sciences), 9(2), 75-84.

Aref, I. M., Atta, H. A. E., Shahrani, T. A., \& Mohamed, A. I. (2011). Effects of seed pretreatment and seed source on germination of five Acacia spp. African Journal of Biotechnology, 10(71), 15901-15910.

Arunraj, R., Skori, L., Kumar, A., Hickerson, N. M., Shoma, N., \& Samuel, M. A. (2020). Spatial regulation of alpha-galactosidase activity and its influence on raffinose family oligosaccharides during seed maturation and germination in Cicer arietinum. Plant Signaling \& Behavior, 1709707.

Assogbadjo, A. E., Kakaï, R. G., Edon, S., Kyndt, T., \& Sinsin, B. (2011). Natural variation in fruit characteristics, seed germination and seedling growth of Adansonia digitata L. in Benin. New Forests, 41(1), 113-125. 
Aubréville, A. (1948). Etude sur les forêts de l'Afrique Equatoriale française et du Cameroun. Nogent-sur-Marne: IRAT, 131 p.

Ayuk, E. T., Duguma, B., Franzel, S., Kengue, J., Mollet, M., Tiki-Manga, T., \& Zenkeng, P. (1999). Uses, management and economic potential of Garcinia kola and Ricinodendron heudeloth in the humid lowlands of Cameroon. Journal of Tropical Forest Science, 11, 746-761.

Baraloto, C., \& Forget, P. M. (2007). Seed size, seedling morphology, and response to deep shade and damage in neotropical rain forest trees. American Journal of Botany, 94(6), 901911.

Baskin, C. C., \& Baskin, J. M. (2014). Germination ecology of seeds with physical dormancy. Seeds: Ecology, Biogeography, and Evolution of dormancy and germination. San Diego: Elsevier Sciences, 145-185.

Baskin, J. M., \& Baskin, C. C. (2019). How much influence does the paternal parent have on seed germination? Seed Science Research, 29(1), 111.

Bewley, J. \& Black, M. (1994). Seeds: physiology of development and germination. 2nd. New York: Edition Plenum Press.

Bischoff, A., \& Müller-Schärer, H. (2010). Testing population differentiation in plant species-how important are environmental maternal effects. Oikos, 119(3), 445-454.

Bischoff, A., Steinger, T., \& Müller-Schärer, H. (2010). The importance of plant provenance and genotypic diversity of seed material used for ecological restoration. Restoration ecology, $18(3), 338-348$.

Boko-haya, Y. Y., Ouinsavi, A. I. N., Houngbeme, G. A., Gbaguidi, F. \& Agbangla, C. (2017). Traditional uses, phytochemistry and in vitro evaluation of toxicity of Ricinodendron heudelotii (Baill Pierre Ex Heckel) leaves in Benin. International Journal of Recent Scientific Research, 8, 21227-21236.
Boulvert, Y. (1996). Geomorphological study of the Central African Republic. 1/1000000 map in two sheets West and East. Paris: ORSTOM.

Breed, M. F., Stead, M. G., Ottewell, K. M., Gardner, M. G., \& Lowe, A. J. (2013). Which provenance and where? Seed sourcing strategies for revegetation in a changing environment. Conservation Genetics, 14(1), 1-10.

Brooks, M. E., Kristensen, K., van Benthem, K. J., Magnusson, A., Berg, C. W., Nielsen, A., ... \& Bolker, B. M. (2017). glmmTMB balances speed and flexibility among packages for zero-inflated generalised linear mixed modeling. The $R$ Journal, 9(2), 378-400.

Busson, F. (1965). Food plants of West Africa: botanical, biological and chemical study, with the technical collaboration of P. Jaeger, P. Lunven and M. Pinta. The Leconte Printing House.

Campos Filho E. M. \& Sartorelli PAR (2015). Guide to the identification of key species for forest restoration in the region of Alto Teles Pires - Mato Grosso. São Paulo: The Nature Conservancy, 248.

Choi G.E., Jin Jeong M., Lee H., Ko C.D., Park J.I., Ghimire, B. (2017) Choi, G. E., jin Jeong, M., Lee, H., Ko, C. D., Park, J. I., \& Ghimire, B. (2017). Morphological Characteristics of Endocarp in Relation to Seed Dormancy of 18 Rubus Species in Korea. Agricultural Life Science Research, 51(6), 15-22.

Côme, D. (1968). Problems of terminology posed by germination and its obstacles. French Plant Physiology Society Newsletter, 14, 3-9.

Cosyns, H., Degrande, A., De Wulf, R., Van Damme, P. \& Tchoundjeu, Z. (2011). Ricinodendron heudelotii (Bail) kernel group commercialisation and its impact on farmers' livelihoods in Cameroon. Journal of Agriculture and Rural Development in the Tropics and Subtropics, 112, 45-56.

Cruz, A., Pérez, B., Velasco, A., \& Moreno, J. M. (2003). Variability in seed germination at the interpopulation, intrapopulation and 
intraindividual levels of the shrub Erica australis in response to fire-related cues. Plant Ecology, 169(1), 93-103.

Debroux, L., Mbolo, M., Delvingt, W., \& Amougou, A. (1998). Régénération du Moabi et du Mukulungu au Cameroun. Prospectives pour l'aménagement. Bois \& Forets Des Tropiques, 255, 5-17.

Dibong, S. D., Ottou, P. B. M., Vandi, D., Ndjib, R. C., Tchamaha, F. M., \& Mpondo, E. M. (2015). Ethnobotany of anti-hemorrhoidal plants in markets and villages in the central and littoral regions of Cameroon. Journal of Applied Biosciences, 96, 9072-9093.

Diouf, M., Samba, S. A. N., Ndoye, O., \& Van Damme, P. (2015). Difference in germination rate of Baobab (Adansonia digitata L.) provenances contrasting in their seed morphometrics when pretreated with concentrated sulfuric acid. African Journal of Agricultural Research, 10(12), 1412-1420.

Djeugap, F. J., Bernier, L., Dostaler, D., Fontem, D. A., \& Avana, M. L. (2014). Germination constraints on Ricinodendron heudelotii in Cameroon. Seed Technology, 61-72.

Événari, M. (1957). The physiological problems of germination. French Plant Physiology Society Newsletter, 3, 105-124.

FAO. (2016). Living and Feeding on the Forest in Central Africa. Rome, Italy: FAO.

Finkelstein, R., Reeves, W., Ariizumi, T. \& Steber C. (2008). Molecular aspects of seed dormancy. Annual Review of Plant Biology, 59, 387-415.

Fredrick, C., Muthuri, C., Ngamau, K., \& Sinclair, F. (2015). Provenance variation in seed morphological characteristics, germination and early seedling growth of Faidherbia albida. Journal of Horticulture and Forestry, 7(5), 127140.

Fredrick, C., Muthuri, C., Ngamau, K., \& Sinclair, F. (2017). Provenance and pre-treatment effect on seed germination of six provenances of Faidherbia albida (Delile) A. Chev. Agroforestry Systems, 91(6), 1007-1017.
Ginwal, H. S., Rawat, P. S., \& Srivastava, R. L. (2004). Seed source variation in growth performance and oil yield of Jatropha curcas Linn. in central India. Silvae genetica, 53(1-6), 186-192.

Harper, J. L. (1977). Population biology of plants. London: Academic Press.

Harrison, P. A., Bailey, G., Vaillancourt, R. E., \& Potts, B. M. (2014). Provenance and seed mass determine the seed germination success of Eucalyptus ovata (Myrtaceae). Seed Science and Technology, 42(3), 466-472.

Heim, F., Guarrigue, E. \& Husson, M. (1919). A new oilseed from Madagascar. The "Betratra". Newsletter of General Colonies Agency, 12, 679-691.

Hossain, M. A., Islam, K. S., Rajasree, N., Hossain, M. K., \& Alam, M. S. (2018). Pre-sowing treatments for improved germination and growth of two rare native species of Bangladesh. Journal of Forestry Research, 29(5), 1277-1282.

Humara, J. M., Lopez, M., Casares, A., \& Majada, J. (2000). Temperature and provenance as two factors affecting Eucalyptus nitens seed germination. Forestry, 73(1), 87-90.

Imchen, C., Sen, S., Kumar, H., \& Marak, J. K. (2015). Effect of Different Pre-treatment Method on Seed Germination of Gulmohar (Delonix regia). Trends in Biosciences, 8, 51055110 .

ISTA. (2005). International rules for seed testing, 1st edn. Bassersdorf: The International Seed Testing Association, pp 1-84.

Kapseu, C., \& Tchiegang, C. (1995). Chemical properties of Ricinodendron heudelotii (Bail.) seed oil. Journal of Food Lipids, 2(2), 87-98.

Katende, A. B., Birnie, A. \& Tengnas, B. O. (1995). Useful trees and shrubs for Uganda. Identification, propagation and management for agricultural and pastoral communities. Regional Soil Conservation Unit (RSCU), Swedish International Development Authority (SIDA). 
Keller, M., \& Kollmann, J. (1999). Effects of seed provenance on germination of herbs for agricultural compensation sites. Agriculture, Ecosystems \& Environment, 72(1), 87-99.

Kheloufi, A., \& Mansouri, L. M. (2017). Effect of sulphuric acid on the germination of a forage tree Acacia nilotica (L.) subsp tomentosa. Livestock Research for Rural Development, 29(2).

Kim, W., Lee, Y., Park, J., Lee, N., \& Choi, G. (2013). HONSU, a protein phosphatase 2C, regulates seed dormancy by inhibiting $\mathrm{ABA}$ signaling in Arabidopsis. Plant and Cell Physiology, 54(4), 555-572.

Kitajima, K. \& Myers, J. A. (2008). Seedling ecophysiology; strategies toward achievement of positive net carbon balance. In Leck, M. A., Parker, V. T., \& Simpson, R. L. (eds), Seedling Ecology and Evolution (pp. 172-188). Cambridge University Press

Kitajima, K. (1994). Relative importance of photosynthetic traits and allocation patterns as correlates of seedling shade tolerance of 13 tropical trees. Oecologia, 98(3-4), 419-428.

Kong, D., Ju, C., Parihar, A., Kim, S., Cho, D., \& Kwak, J. M. (2015). Arabidopsis glutamate receptor homolog3. 5 modulates cytosolic $\mathrm{Ca} 2+$ level to counteract effect of abscisic acid in seed germination. Plant Physiology, 167(4), 16301642.

Kouame, N., Soro, K., Mangara, A., Diarrassouba, N., Koulibaly, A., \& Boraud, N. (2015). Physico-chemical study of seven (7) spontaneous food plants from the centralwestern part of Côte d'Ivoire. Journal of Applied Biosciences, 90, 8450.

Kumar, S., Radhamani, J., Singh, A. K., \& Varaprasad, K. S. (2007). Germination and seed storage behaviour in Pongamia pinnata L. Current Science, 93(7), 910-911.

Ky-Dembele, C., Tigabu, M., Bayala, J., \& Odén, P. C. (2014). Inter-and intra-provenances variations in seed size and seedling characteristics of Khaya senegalensis A. Juss in
Burkina Faso. Agroforestry Systems, 88(2), 311320.

Lagou, S. M. L., Bi, F. H. T., Yao, K., Bakayoko, A., \& Kone, M. W. (2016). Fistules obstétricales dans le district d'Abidjan, Côte d'Ivoire: niveau de connaissance et plantes utilisées traditionnellement dans le traitement. International Journal of Biological and Chemical Sciences, 10(3), 1273-1285.

Leakey, R. R., \& Tomich, T. P. (1999). Domestication of tropical trees: from biology to economics and policy. Agroforestry in Sustainable Agricultural Systems, 319-338.

Lee, H. G., Lee, K., \& Seo, P. J. (2015). The Arabidopsis MYB96 transcription factor plays a role in seed dormancy. Plant Molecular Biology, 87(4-5), 371-381.

Liu, X., Xu, D., Yang, Z., \& Zhang, N. (2017). Geographic variations in seed germination of Dalbergia odorifera $\mathrm{T}$. Chen in response to temperature. Industrial Crops and Products, $102,45-50$

Mapongmetsem, P. M., Duguma, B., Nkongmeneck, B. A., \& Selegny, E. (1999). The effect of various seed pre-treatments to improve germination in eight indigenous tree species in the forests of Cameroon. Annals of Forest Science, 56(8), 679-684.

Marie-Thérèse, K. N. D., Modeste, G. G., \& Ali, M. A. N. G. A. R. A. (2012). Essais de germination de Ricinodendron heudelotii (Euphorbiaceae) dans la région du Fromager au centre-ouest de la Côte d'Ivoire. Journal of Applied Biosciences, $56,4133-4141$.

Mira, S., González-Benito, M. E., Ibars, A. M., \& Estrelles, E. (2011). Dormancy release and seed ageing in the endangered species Silene diclinis. Biodiversity and Conservation, 20(2), 345-358.

Moya, R. S., Meza, S. E., Díaz, C. M., Ariza, A. C., Calderón, S. D., \& Peña-Rojas, K. (2017). Variability in seed germination and seedling growth at the intra-and inter-provenance levels of Nothofagus glauca (Lophozonia glauca), an 
endemic species of Central Chile. New Zealand Journal of Forestry Science, 47(1), 10.

N'guessan, K., Konan, E. K., \& Tiébré, M. S. (2009). Plantes utilisées dans le traitement des troubles gynéco-obstétriques par les peuples Abbey et Krobou d'Agboville (Côte-d'Ivoire). Phytothérapie, 7(5), 262.

N'guessan, K., Zirihi, N. G. \& Boraud, N. (2011). Ethnopharmacological study of plants used to facilitate childbirth in Abbey and Krobou country, southern Côte d'Ivoire. International Journal of Biological and Chemical Sciences, 4, 1004-1016.

Ngene, J. P., Ngoule, C. C., Kidik Pouka, C. M., Mvogo Ottou, P. B., Ndjib, R. C., Dibong, S. D., \& Mpondo Mpondo, E. (2015). Importance in the traditional pharmacopoeia of flavonoid plants sold in the markets of Douala Est (Cameroon). Journal of Applied Biosciences, 88, 8194-8210.

Nole, T., Lionel, T. D. W., Cedrix, T. F. S., \& Gabriel, A. A. (2016). Ethnomedical and ethnopharmacological study of plants used for potential treatments of diabetes and arterial hypertension by indigenous people in three phytogeographic regions of Cameroon. Diabetes Case Rep, 1(110), 2.

Ojo, M. O., \& Ezekiel, A. (2019). Effect of Provenance Variations on the Growth and Development of Terminalia ivorensis (A Chev). Current Journal of Applied Science and Technology, 37, 1-7.

Pasonen, H. L., Pulkkinen, P., \& Käpylä, M. (2001). Do pollen donors with fastest-growing pollen tubes sire the best offspring in an anemophilous tree, Betula pendula (Betulaceae)? American Journal of Botany, 88(5), 854-860.

Penfield, S. (2017). Seed dormancy and germination. Current Biology, 27(17), R874R878.

Pérez-García F., Varela F., \& González-Benito M.E. (2012). Morphological and germination response variability in seeds of wild Bellow gentian (Gentiana lutea L.) accessions from northwest Spain. Botany, 90, 731-742.

Pérez-García, F., \& González-Benito, M. E. (2010, August). Intrapopulation variation in seed germination of six rockrose (Cistus L.) species. In XXVIII International Horticultural Congress on Science and Horticulture for People (IHC2010): International Symposium on 937 (pp. 379-384).

Pinheiro, J., Bates, D., DebRoy, S., Sarkar, D., \& Team, R. C. (2017). nlme: Linear and nonlinear mixed effects models. $R$ Package Version, 3(1), 111.

Podda, L., Santo, A., Mattana, E., Mayoral, O., \& Bacchetta, G. (2018). Inter-and intra-variability of seed germination traits of Carpobrotus edulis $\mathrm{NE} \mathrm{Br}$. and its hybrid $\mathrm{C}$. affine acinaciformis. Plant Biology, 20(6), 1059-1067.

$\mathrm{R}$ Core Team. (2019). $R$ : A language and environment for statistical computing. Vienna, Austria: R Foundation for Statistical Computing.

Roach, D. A. \& Wulff, R. D. (1987). Maternal effects in plants. Annual Review of Ecology and Systematics, 18, 209-235.

Saki, S. J., Mosso, K., Sea, T. B. \& Diopoh, K. J. (2005). Determination of some essential components of Akpi almonds (Ricinodendron heudelotii) in the Ivory Coast. African Agronomy, 17, 137-142.

Santo, A., Mattana, E., \& Bacchetta, G. (2015). Inter-and intra-specific variability in seed dormancy loss and germination requirements in the Lavatera triloba aggregate (Malvaceae). Plant Ecology and Evolution, 148(1), 100-110.

Shu, K., Liu, X. D., Xie, Q., \& He, Z. H. (2016). Two faces of one seed: hormonal regulation of dormancy and germination. Molecular Plant, 9(1), 34-45.

Shu, K., Zhang, H., Wang, S., Chen, M., Wu, Y., Tang, S., ... \& Xie, Q. (2013). ABI4 regulates primary seed dormancy by regulating the biogenesis of abscisic acid and gibberellins in Arabidopsis. PLoS Genet, 9(6), e1003577. 
Sokpon, N. (1995). Natural regeneration in gaps of the Pobe semi-deciduous forest, south-east Benin. Belgian Journal of Botany, 128(1), 1332.

Sudrajat, D. J., Nurhasybi, N., Siregar, I. Z., Siregar, U. J., Mansur, I., \& Khumaida, N. (2016). Intraspecific variation on early growth of Neolamarckia cadamba Miq. in provenanceprogeny tests in West Java Province, Indonesia. BIOTROPIA-The Southeast Asian Journal of Tropical Biology, 23(1), 10-20.

Tabuna, H. (1999). The Central African non-timber forest products market in France and Belgium. Occasional paper, (19).

Tchiegang, C., Dandjouma, A. A., Kapseu, C., \& Parmentier, M. (2003). Study of the conditions of oil extraction by pressing the almonds of Ricinodendron heudelotii (Baill.) Pierre ex Pax. Journal of Food Engineering, 58, 363-371.

Tchiegang, C., Kapseu, C., Ndjouenkeu, R., \& Ngassoum, M. B. (1997). Amandes de Ricinodendron heudelotii (Bail.): matière première potentielle pour les industries agroalimentaires tropicales. Journal of Food Engineering, 32(1), 1-10.

Van Zandt, P. \& Mopper, S. (2004). The effects of maternal salinity and seed environment on germination and growth of Iris hexagona. Evolutionary Ecology Research, 6, 813-832.

Venier, P., Ferreras, A. E., Verga, A., \& Funes, G. (2015). Germination traits of Prosopis alba from different provenances. Seed Science and Technology, 43(3), 548-553.

Vivien, J. \& Faure, J. J. (1985). Trees of the dense forests of Central Africa. Paris (France): Agency for Cultural and Technical Cooperation.

Vivien, J. \& Faure, J. J. (1996). Wild fruit trees of Africa: species from Cameroon. Ministry of Cooperation: Technical Centre for Agricultural and Rural Cooperation.

Ye, X., Li, L., Baskin, C. C., Baskin, J. M., Du, J., \& Huang, Z. (2019). Sand burial helps regulate timing of seed germination of a dominant herb in an inland dune ecosystem with a semiarid temperate climate. Science of The Total Environment, 680, 44-50. 